\title{
Examining the Lacunae in the International Aviation Regime in the Context of the MH 17 Incident
}

Jaideep Kodali*

\begin{abstract}
In this paper, the researcher examines the liability regime that governs the international aircraft carriers in the context of the recent Malaysian plane (MH 17) crash. The researcher analyses the efficacy of the Warsaw and Montreal Convention frameworks in affixing liability on the state parties. The international aviation regime as regulated by the ICAO and its inability to confirm legal responsibility is also dealt with in reference to the previous incidents of air crash. The paper concludes on a note that the international aviation regime is not adequately equipped to deal with questions of state responsibility for acts of unlawful interference with international civil aviation regime.
\end{abstract}

Keywords: Aircraft Carriers, International Civil Aviation Organisation, Liability Regime, Montreal Convention, State Responsibility.

\section{Introduction}

The aviation industry is on a sharp ascent and the flow of traffic has increased with the advent of globalization. ${ }^{1}$ As of 2014 , the

* Student, National Academy of Legal Studies and Research, Hyderabad; jaideep.kodali@gmail.com

1 Ken Button, The Impacts of Globalisation on International Air Transport Activity, Global Forum on Transport and Environment in a Globalising World, (Nov. 12, 2008), available at http://www.oecd.org/ greengrowth/greening-transport/41373470.pdf. 
aviation industry supports more than 58 million jobs and \$2.1 trillion of economic activity annually. In 2013, there were 3 billion passengers who chose to travel by air and a steady increase in air travel can be attributed to the fact that air travel is no longer perceived to be unsafe. ${ }^{2}$

In order to protect the interests of the passengers in case of accidents or loss of baggage, the aircrafts are also liable to pay passengers adequate compensation. It was in furtherance of this objective that 108 nation states across the world have signed and ratified the Montreal Convention which imposes the liability for any losses incurred by the passengers on the aircraft carriers. It is a fair and uniform international regime to protect the interests of the passengers and the Convention came into force in 1999. Out of the 191 contracting states who are parties to the International Civil Aviation Organisation (hereinafter ICAO), only 108 contracting states have ratified this treaty and many passengers are still not under the protection of this treaty. ${ }^{3}$

However, the current aviation regime is not void of glitches as only a bare minimum compensation is provided when the accidents on the aircrafts are not a result of the negligent acts of the air carrier. This paper seeks to examine this problem in the light of the recent Malaysian Airlines (MH 17) aircraft disaster in Ukraine which was shot down by the rebels who were controlling parts of Ukraine. This air disaster raises serious questions about the safety of passengers in the international skies that could affect the credibility of the aviation industry. This incident has potentially exposed to the whole world, the problems in the current international treaty regimes on passenger liability as the victims of this air disaster were not protected.

2 RuWAntissa Abeyratne, Aviation Security LaW 190 (Springer Publications 1st ed. 2010).

3 Convention for the Unification of Certain Rules for International Carriage by Air, Oct. 12, 1929, 49 Stat. 3000 (1934), 137 L.N.T.S. 11, available http://www.jus.uio.no/lm/air.carriage.warsaw.convention.1929/doc.h tm. 
This is closely related to the flaws in the constitution of ICAO which is merely a regulatory body and does not have the necessary power to impose sanctions on contracting states for not taking necessary precautions to ensure the safety of passengers. In the first part of the paper, the researcher discusses the events that have led to the crash, following which the liability under the international treaty regimes are discussed in the second part. In the third part, the scope of liability on Malaysian Airlines under the Montreal Convention is analysed. In the fourth part, the paper examines the role of the ICAO in resolving the disputes on liability. The paper concludes by examining the changes that need to be made to the toothless ICAO.

\section{The 'Other' Tragedy in Crimea: How the MH 17 Went Down?}

The Malaysian Airlines Flight17 (MH 17) took off from the Amsterdam Airport, Schiphol on July 17, 2014 and was scheduled to arrive at the Kuala Lumpur International Airport. As per the flight plan, the aircraft was scheduled to fly over Ukraine at FL 350 but it was later shifted to FL 330 to avoid potential conflict with the flight plan of another plane. ${ }^{4}$ As the flight approached the Crimean territory, the Dnipro Control had contacted the Russian air control for clearance for MH 17. They tried contacting MH 17and there was no response. The air control noticed that the Boeing 777 went missing from their radar at 4:54pm (Greenwich Mean Time) which was earlier cruising at 33,000 feet. ${ }^{5}$

As a result of the Crimean crisis brewing in eastern Ukraine, many airlines began to avoid the airspace over Crimea. The ICAO had warned its members that commercial passengers would be at risk. ${ }^{6}$

${ }^{4}$ MH 17: Malaysia Airlines Could Be Sued Over Flight Path, News.CoM.AU, (Sep. 21, 2014), http://www.news.com.au/travel/travel-updates/mh17malaysia-airlines-could-be-sued-over-flight-path/story-fnizu68q1227065232259.

${ }^{5}$ MH 17 Malaysia plane Crash in Ukraine: What We Know, BBC NEWS, (Sep. 09, 2014), http://www.bbc.com/news/world-europe-28357880.

${ }^{6}$ Luis Fonseca de Almeida, Safety of Civil Aircraft Operating in the Simferopol Flight Information Region (FIR), INTERNATIONAL CIVIL AVIATION ORGANISATION, (Apr. 2, 2014), available at http://www.ibac.org/wp- 
However, many reputed international airlines continued using this troubled airspace risking the lives of the passengers until the crash of $\mathrm{MH} 17$.

All the 283 passengers and 15 crew on board in the aircraft had died. Preliminary investigation reports had suggested that MH 17 had crashed after being hit by a high velocity object. ${ }^{7}$ The Ukrainian government had accused the rebel forces of downing the plane using a Soviet era SA 11 ground-to-air missile and similar attacks were carried out on Ukrainian military aircrafts. ${ }^{8}$

Eye witness account described that, the plane broke into two while in the air and crashed near Torez in Donetsk Oblast, Ukraine. A preliminary investigation carried out by the Dutch investigators concluded that MH 17 was hit by 'multiple high velocity objects.' According to the report, the pattern of damage observed did not indicate any failure of the aircraft and the aircraft was also in airworthy condition to make the flight to Kuala Lumpur. All crew on the aircraft were properly licensed and it clearly indicated that the crash was not a result of aircraft failure. ${ }^{10}$

Since the crash had taken place over a conflict ridden area, none of the nation states took responsibility for the crash. The Ukrainian government had blamed the Russian backed rebels in Crimea calling this a terrorist attack. The rebel leaders have denied this, claiming that they lacked the weaponry to shoot down a Boeing 777.

In the light of the aforementioned circumstances, this paper will examine the Convention for the Unification of Certain Rules for

content/uploads/2010/06/14-0243-Safety-of-civil-aircraft-in-

Simferopol-FIR.pdf.

7 Preliminary Safety Report: Crash involving Malaysian Airlines Boeing 777-200 Flight MH 17, DUTCH SAFETY BOARD, 7 (Jul. 7, 2014), available at http:/ / www.onderzoeksraad.nl/uploads/phasedocs/701/b3923acad0ceprem-rapport-MH 17-en-interactief.pdf.

8 Malaysian Airliner Downed in Ukraine War Zone, 295 dead, (Jul. 17, 2014), available at http://www.reuters.com/article/2014/07/17/us-ukrainecrisis-airplane-idUSKBN0FM22N20140717.

9 DUTCH SAFETY BOARD, supra note 7.

10 DUTCH SAFETY BOARD, supra note 7. 
International Carriage by Air also referred to as the Montreal Convention, 1999 in order to analyse the liability of the air carriers towards its passengers.

\section{Liability of Air Carriers under International Conventions}

The passengers in the aviation industry are the most vulnerable stakeholders. Any damage that arose from accidents during their flight journey was not governed by any legal mechanism until the signing of the Warsaw Convention in 1929.11 This was followed by the Convention for the Unification of Certain Rules for International Carriage by Air, 1999 signed at Montreal.

These conventions address the problem of aircraft carriers' liability to the passengers on board international flights, for loss of lives in aircraft crashes, injuries to passengers, missing and misplaced. In this section, the paper will first discuss the Warsaw Convention and then examine the Montreal Convention.

\section{Warsaw Convention, 1929}

The Convention for the Unification of Certain Rules Relating to International Carriage by Air was signed at Warsaw in 1929 to regulate liability for international carriage of luggage, human beings or goods. It was further amended through The Hague Protocol, 1955 and The Guatemala City Protocol, 1971.

One of the important elements of the Warsaw Convention was to limit the liability on the commercial airlines in case of liability. The primary objective of the Convention was to establish an international regime that will regulate the liability of aircrafts towards its passengers. However the upper limit on compensation was insufficient and the Convention was no longer fair and was against the interests of the passengers. The compensation was so inadequate that the subsequent protocols at Hague and Guatemala had to increase the upper limit on aircraft liability.

${ }^{11}$ Convention for the Unification of Certain Rules Relating to International Carriage by Air, Oct. 12, 1929, 137 L.N.T.S. 11 available at http://www.jus.uio.no/lm/air.carriage.warsaw.convention.1929/doc.h tml. 
The Warsaw regime continued to be unfair to the passengers. Under this Convention, there is a presumption that the airlines are liable for injuries or death of passengers. It must thus be shown that, the damage caused to the passenger was intentional and reckless, a standard of proof that is very high. However, the airlines can be shielded from liability if it is established that they had taken all necessary measures to avoid the damage.

This can be seen as per Article 20 of the Warsaw Convention which states that,

The carrier is not liable if he proves that he and his agents have taken all necessary measures to avoid the damage or that it was impossible for him or them to take such measures. ${ }^{12}$

This clearly indicates the limitations on the liability which the Convention imposes on commercial airliners. It leaves the passengers high and dry in circumstances where the situation falls in the grey areas.

Further, this Convention does not provide any advance payments for the passengers to cover their urgent economic needs. ${ }^{13}$ This is necessary as the families would be under severe economic stress as a result of the losses they have incurred and to also due to the costs involved in litigation.

\section{Montreal Convention, 1999}

The position in Montreal Convention shifts considerably in favour of the passengers when it comes to the question of liability. ${ }^{14}$ This must be observed in the light of the booming aviation industry which gives primary importance to safety.

${ }^{12}$ Convention for the Unification of Certain Rules Relating to International Carriage by Air, Oct. 12, 1929, 137 L.N.T.S. 11 available at http://www.jus.uio.no/lm/air.carriage.warsaw.convention.1929/doc.h tml.

13 Bin Cheng, A New Era in the Law of International Carriage by Air: From Warsaw (1929) to Montreal (1999), 53, I.C.L.Q., 838, 833-859 (2004).

14 PATrick ZeUner, THE LAW OF INTERnATIONAL CARRIAGE BY AIR 15 (Grin Verlag 1st ed. 2013). 
As per the Convention, to establish the liability of the carrier, certain conditions need to be fulfilled as mentioned under Article 17 of the Montreal Convention. It must first be established that an accident has occurred which has resulted either in 'death or bodily injury.'15 Further, it must be established that the accident has occurred when the passengers were inside the aircraft or were in the process of embarking or disembarking from the aircraft.

The Convention has removed the upper limit on compensation to passengers. In order to balance the interests of passengers and the aircraft carriers, the liability regime was modified to include two tier liabilities. As per this innovative introduction taken from the Japanese Agreement, the aircrafts would be 'strictly liable' under any circumstance when the damages do not exceed 1,00,000 SDR's. ${ }^{16}$ The passengers are not under an obligation to establish the fault as it is already presumed. ${ }^{17}$ To claim further damages, the negligence test must be fulfilled.

The second tier of liability is 'fault based liability'. Under the Montreal regime, airlines are responsible only when liability is a result of negligent or reckless behaviour. If the airlines can establish that they have taken all reasonable care to prevent an accident, the aircraft can escape liability. ${ }^{18}$ As interpreted in the case of Air France v. Saks ${ }^{19}$ by the United States Supreme Court, the liability will arise when the injury is caused by a sudden or unexpected event, other than usual operation which is external to the passenger. The provisions of the Montreal Convention as per Article 20 relevant to this principle are as follows:

When by reason of death or injury of a passenger compensation is claimed by a person other than the

${ }^{15}$ Montreal Convention for the Unification of Certain Rules for International Carriage by Air art. 20,May 28, 1999, 2242 U.N.T.S. 309.

${ }^{16}$ Convention for the Unification of Certain Rules for International Carriage by Air art. 21, May 28, 1999, 2242 U.N.T.S. 309.

17 Roberta L. Wilensky, Flying the Unfriendly Skies: The Liability of Airlines under the Warsaw Convention for Injuries Due to Terrorism, 8 N. W. J. INT'L L. BUS. 248, 279-283 (1987-1988).

18 GEORGE N. TOMPKINS, Liability Rules APPliCABle tO INTERNATIONAL AIR TRANSPORTATION 285 (1st ed. 2002).

19 Air France v. Saks, 470 U.S. 392 (1985). 
passenger, the carrier shall likewise be wholly or partly exonerated from its liability to the extent that it proves that the damage was caused or contributed to by the negligence or other wrongful act or omission of that passenger. ${ }^{20}$

The test to determine the liability has not changed since the Warsaw Convention and has largely remained the same. The Courts in the United States have interpreted this test to mean wilful misconduct on part of the airlines. In the case of American Airlines v. Ulen, ${ }^{21}$ the Court held that:

Now, wilful misconduct is not, as I have said, merely misconduct, but wilful misconduct. So if the carrier, or its employees or agents, wilfully performed any act with the knowledge that the performance of that act was likely to result in injury to a passenger, or performed that act with reckless and wanton disregard of its probable consequences, then that would constitute wilful misconduct. ${ }^{22}$

This is clearly in conformity with Article 20 of the Montreal Convention as it makes the aircraft carriers liable for wrongful acts and acts of negligence. ${ }^{23}$ Further in the more recent case of Piamba Cortes v. American Airlines, the United States Court of Appeals has broadened the scope of liability. ${ }^{24}$ According to this, the commission or omission of an act that is likely to cause injury to passengers and threaten their safety would make the carrier liable to pay compensation. ${ }^{25}$

${ }^{20}$ Convention for the Unification of Certain Rules for International Carriage by Air art. 20, May 28, 1999, 2242 U.N.T.S. 309.

21 American Airlines, 186 F.2d 529, (DC Cir. 1949).

22 American Airlines v. Ulen, 186 F.2d 529 (1949).

23 af Irene Larsen, Regime of Liability in Private International Air Law - with Focus on the Warsaw System and the Montreal Convention of 28 May 1999, JURIDISKINSTITUT: PART OF SCHOOL OF BUSINESS AND SOCIAL SCIENCES, http:/ /law.au.dk/fileadmin/site_files/filer_jura/dokumenter/forsknin g/rettid/2002/speciale-20020002.pdf (last visited Feb. 13, 2015).

24 Piamba Cortes, 177 F.3d 1272 (1999).

${ }^{25} \mathrm{Id}$. 
These tests assist in making the passengers unburdened of the farce of establishing the fault and relieving the burden of proof thereby shifting the onus on to the carrier. It is also only in exceptional circumstances that negligence can exonerate the carrier either partly or in full.

In the light of this discussion, the author shall now proceed to determine the liability of Malaysian Airlines towards the families of the passengers who lost their lives in the MH 17air crash.

\section{The Scope of Liability of Malaysian Airlines}

In the aforementioned paragraphs, it has been established that there is a two tier liability regime for passengers. The first tier holds the aircraft carrier strictly liable and the aircraft carriers must pay the victims interim compensation. The Malaysian Airlines, according to the Montreal Convention is required to pay a sum of $\$ \mathrm{US183,000}$ and it has already paid $\$ \mathrm{US50,000}$ to all families. ${ }^{26}$ The Malaysian Airlines has pledged to pay the remainder of the amount also.

The passengers may be entitled to more compensation from the second tier of liability under the Montreal regime. In order to invoke the second tier to determine the liability, it must be shown that the injury caused was not as a result of negligent or wrongful act of the aircraft carrier. ${ }^{27}$ Let us now examine the conduct of Malaysian Airlines preceding the air crash.

The violence in Crimea erupted in 2013 and many airliners have been avoiding the conflict ridden zone. The rebels have downed multiple Ukrainian military aircrafts and it was common knowledge that they were in possession of anti aircraft missile weapons. ${ }^{28}$

${ }^{26} \mathrm{MH} 17$ Compensation Could Hit \$1 Billion in Latest Disaster for Malaysia Airlines, NEws.COM.AU (Nov. 26, 2014), http://www.news.com.au/ travel/travel-updates/ $\mathrm{MH}$ 17-compensation-could-hit-1nbspbillion-inlatest-disaster-for-malaysia-airlines/story-fnizu68q-1227000111037.

27John Balfour, The Montreal Convention 1999 - A Solution To The Limitations Of The Warsaw Convention 3 INT'L TRAVEL L.J., 143-147 (1999).

28 NEWS.COM.AU, supra note 4. 
At this juncture, the author would like to draw attention to the provisions of the Chicago Convention, 1944 which vests the responsibility of ensuring the safety of aircrafts on the member states. This can be seen in the preamble to the Convention which has emphasised that the future development of international civil aviation is through cooperation as its abuse can become a grave threat to general security. ${ }^{29}$ In order to facilitate freedom of air, the contracting States under Article 21 of the Convention are required to provide air navigation facilities to aid in air navigation. ${ }^{30}$ The first freedom in travelling by air as laid down in Chicago Convention requires scheduled air services to ply only when the special permission or authorisation is provided. ${ }^{31}$

In the present situation, the precarious climate in Crimea was informed to all the contracting state parties. The ICAO had issued the following directive before the accident:

Due to the unsafe situation where more than one ATS provider may be controlling flights within the same airspace from 3 April 2014, 0600 UTC onwards, consideration should be given to measures to avoid the airspace and circumnavigate the Simferopol FIR with alternative routings. ${ }^{32}$

On the basis of this, the European Aviation Safety Agency issued a Safety Information Bulletin on April 3, 2014 appraising member carriers of the security situation in Simferopol FIR (Crimean air space).

In the instant case, the aircraft carrier may seem to be at fault as it was unmindful to fly over a conflict ridden territory that has

${ }^{29}$ Convention on International Civil Aviation Preamble, Dec.07, 1944, 15 U.N.T.S. 295.

30 Convention on International Civil Aviation art. 21, Dec. 07, 1944, 15 U.N.T.S. 295.

31 The International Air Services Transit Agreement art. 1, Dec. 07, 1944, 84 U.N.T.S 389.

${ }^{32}$ Luis Fonseca de Almeida, ICAO State letter on Ukraine EUR/NAT 140243.TEC (FOL/CUP),ICAO, (Apr. 02, 2014),http://www.ibac.org/wpcontent/uploads/2010/06/14-0243-Safety-of-civil-aircraft-inSimferopol-FIR.pdf. 
caused this accident. However, the advisories issued by the ICAO are not legally binding on the aircraft carriers.

As per Article 9 of the Chicago Convention, the contracting parties can cordon the portions of their airspace. ${ }^{33}$ The relevant portion of Article 9 reads as follows: "Each contracting State may, for reasons of military necessity or public safety, restrict or prohibit uniformly the aircraft of other States....."34

It is submitted by the author that the accident could have been averted if the airspace was closed by the aviation authorities in Ukraine. The Malaysian Airlines and other airlines such as Lufthansa and Emirates operating in the route would not have had the necessary clearances to use the conflict ridden airspace had the route been closed.

As per the instructions issued by the Ukrainian Air Traffic Controller (ATC), aircrafts were not permitted to fly under 32,000 feet as the same was closed on account of conflict in Crimea. ${ }^{35} \mathrm{MH}$ 17 was cruising at an altitude of 33,000 feet when it was hit by a missile. ${ }^{36}$ According to John Cox, a former pilot and aviation safety consultant, the airlines flying just above the restricted altitude did not risk the lives of passengers as a safety margin is built in, while prescribing it. ${ }^{37}$ It is expedient to note that the request of the aircraft to shift to 35,000 feet was denied by the ATC and the disaster could have been averted had this been done.

33 Luis Fonseca de Almeida, ICAO State letter on Ukraine EUR/NAT 140243.TEC (FOL/CUP),ICAO, (Apr. 02, 2014),http://www.ibac.org/wpcontent/uploads/2010/06/14-0243-Safety-of-civil-aircraft-inSimferopol-FIR.pdf.

${ }^{34} \mathrm{Id}$.

35 Dan Milmo, Downed Malaysia Airlines plane: how did it go wrong for flight $\mathrm{MH}$ 17?,THE GUARDIAN, (Jul. 17, 2014) http://www.theguardian.com/world/ 2014/jul/17/malaysia-airlinesmh17-flying-just-above-restricted-airspace.

36 DUTCH SAFETY REPORT, supra note 7.

37 Aviation Experts from Around the World Comment on Preliminary MH 17: Report, SPUTNIKNEW.COM, (Sep. 10, 2014), http:/ / en.ria.ru/analysis/20140910/192804880/ Aviation-Experts-FromAround-the-World-Comment-on-Preliminary-MH 17-Report.html. 
The above discussion clearly establishes that, the Malaysian Airlines had not committed any negligent or wrongful act that would jeopardise the safety of the passengers. It had the requisite clearances from Ukrainian ATC to enter the airspace over Crimea and it had followed the instruction of navigating over the restricted airspace that was closed. Although there were safety bulletins issued by ICAO, they were merely advisories and were not legally binding on the airline carriers to comply with. The question still remains as to who is liable for the crash.

\section{Role of State Parties under the Chicago Convention}

As stated earlier, the passengers cannot hold the Malaysian Airlines liable, and to seek remedies they can initiate an action against the State of Ukraine. However, this will give rise to endless litigation and it may take decades to compensate the passengers who suffered damages.

The ICAO and the various conventions that deal with passenger liability are ill equipped to deal with these situations as State Parties can claim sovereign immunity when liability is imposed on them. ${ }^{38}$ The ICAO has historically exercised moderation and restraint when it faced situations that required the imposition of liability on a contracting state as it does not have the means to enforce its decision. ${ }^{39}$ Over the years, it has been functioning effectively through cooperation and it cannot reconcile the principle of complete and exclusive sovereignty of State Parties with the obligation to ensure security of aircrafts. ${ }^{40}$

In the Lockerbie bombing case when agents of the Libyan government had planted bombs which detonated in air, the liability was affixed on the State of Libya even though President Gadaffi had denied legal responsibility. However, the Libyan government

38 S.P. Sundaram, Peace through Co-operation: The ICAO Example, 34(2) PEACE RESEARCH, 95-100 (2002).

${ }^{39}$ Eugene Sochor, ICAO and Armed Attacks against Civil Aviation 44(1) INT'L J. 134-170 (1988) available at http:/ / www.jstor.org/stable/40202582.

40 Ruwantissa Abeyratne, Terror in the Skies: Approaches to Controlling Unlawful Interference with Civil Aviation, 11(2) INTERNATIONAL JOURNAL OF POLITICS, CUlTuRE, AND SOCIETy 245, 245- 258 (1996). 
taking a high moral responsibility had agreed to pay compensation to victims of the disaster.

In the bombing of the Gaza International Airport and air navigation facilities, the legal responsibility for air crash was affixed on the state of Israel. Israel had cited the reason that it suspected Palestine was using the airport to smuggle weapons through the airport. The ICAO strongly condemned the acts of Israel and had urged it to take the burden of restoring operations in Israel.

In the aftermath of the Iran Air Flight 655, when repeated requests were made by Iran to ICAO to intervene, the ICAO expressed regret for events and did not even condemn the United States for its actions.41 The government of Iran had to approach the International Court of Justice to claim compensation for the victims of the air crash. This could be a possible course of action in the present case as well. ${ }^{42}$

There are eerie similarities between the air crash of IAF 655 and $\mathrm{MH} 17$; let us examine this case to understand the question of passenger liability. In the crash of Iran Air Flight 655, an American warship in Iranian waters had shot down the civilian aircraft. The IAF 655 was navigating in the civilian aircraft route and was hit by a missile from USS Vincennes killing all 290 people on board. ${ }^{43}$ The Islamic Republic of Iran approached the International Court of Justice and the United States had made an out of court settlement

${ }^{41}$ International Civil Aviation Organization: Resolution and Report Concerning the Destruction of Iran Air Airbus 3 July, 1988, 28(4)INTERNATIONAL LEGAL MATERIALS, 896-943 available at http://www.jstor.org/stable/20693341.

42 International Court of Justice: Application Instituting Proceedings in Case Concerning Aerial Incident 3 July 1988 (Iran v. United States) 28(4) INTERNATIONAL LEGAL MATERIALS, 842-846 (1989) available at http://www.jstor.org/stable/20693336.

${ }^{43}$ Andreas F. Lowenfeld, Economic Sanctions: Looking Back and Looking Ahead, 88 MicH. L. ReV. 1931-1939 (1990). 
of USD 61.8 million for all the victims without admitting legal responsibility. ${ }^{44}$

The air traffic controller and the aviation department in Ukraine have clearly failed in their duty to close the airspace over conflict ridden area. Every contracting State of the Chicago Convention is under a duty to provide aircraft carriers, airspace that is safe and secure. Failing to do this would clearly affect the confidence of passengers in the aviation sector that would in turn greatly affect the aviation industry. 45

Further, the Ukrainian government is vicariously liable for the acts of its rebels in the Crimean region for shooting down $\mathrm{MH}$ 17with an anti aircraft missile. It was under a duty to ensure that security conditions were adequate and did not interfere with civil aviation. The acts of rebel forces are in violation of customary international law and many internationally recognized human rights covenants that protect civilians during times of wars. ${ }^{46}$ The State of Ukraine must take responsibility for their actions as the victims of the crash cannot sue the rebel forces for the crash.

The victims in $\mathrm{MH}$ 17case may move their respective governments to raise an issue with the International Court of Justice on this matter. The jurisdiction maybe invoked under the Chicago Convention as per Article 84 which deals with settlement of disputes $^{47}$ i.e. if there is a disagreement between two or more contracting states concerning a dispute that cannot be settled by negotiation then the matter may be appealed from the ICAO to the International Court of Justice. ${ }^{48}$ This issue would lead to a

${ }^{44}$ Marian Nash Leich, Denial of Liability: Ex Gratia Compensation on a Humanitarian Basis, THE AM. J. INT'L L. 319, 321 (1989).

${ }^{45}$ Associated Press, Aviation's Terrible Week Doesn't Mean Flying is Less Safe, Say Experts, PBS NEWSHOUR, (Jul. 24, 2014), available at http:/ / www.pbs.org/newshour/rundown/aviations-terrible-weekdoesnt-mean-flying-less-safe-say-experts.

${ }^{46}$ Alexis Flynn, Will the MH 17 Disaster Be Prosecuted as a War Crime?, THE WALL STREET JOURNAL: LAW BLOG, (Jul. 22, 2014), http://blogs.wsj.com/law/tag/mh17/.

47 Convention on International Civil Aviation art. 86, Dec. 07, 1944, 15 U.N.T.S. 295.

48 Id. 
prolonged litigation as was in the case of Islamic Republic of Iran v. United States of America ${ }^{49}$ which albeit prematurely ended with a settlement, had taken 8 years to be resolved. ${ }^{50}$

In the light of this, the author submits that, the international aviation regime is not adequately equipped to deal with questions of state responsibility for acts of unlawful interference with international civil aviation. Thus the victims of $\mathrm{MH} \mathrm{17may} \mathrm{have} \mathrm{to}$ wait for a long time for before the compensation, for the loss of their loved ones in the air crash, is granted.

\section{Conclusion}

Passenger liability in civil aviation is a vital area for the sustenance of civil aviation. The confidence in the civil aviation industry could be easily affected if the interests of the passengers are not considered. The various conventions on passenger liability do offer protection to passengers by letting them hold the international air carriers liable through a two tier liability. At one level, there is strict liability which is imposed on aircrafts for any act that causes death or bodily injury wherein it paysminimum compensation to all passengers. At the second level, the air carrier would be liable to pay any further compensation if it is established that the accident was a result of its act of negligence. This passenger liability regime has evolved from the Warsaw Convention in a progressive manner as passengers are now guaranteed a bare minimum compensation from the aircraft carriers.

These conventions have failed to cover those instances when the accident takes place as a result of the interference with the civil aviation. There have been views put forth that the whole liability to compensate must be imposed on the aircraft carriers. In the humble opinion of the researcher, this would be rather unfair as it imposes a financial strain on the aircraft carriers.

The arguments raised by the author clearly indicate the absence of any regulator to impose sanctions on states that do not ensure that their airspaces are safe. The ICAO has come into existence with an

49 ICJ: Aerial Incident, supra note 42.

50 Leich, supra note 44. 
intention to foster cooperation among states to ensure that the airspaces are safe for navigation. However, it has been unable to fulfil its obligations as its role is reduced to a mere regulator that looks into the commercial aspects of civil aviation. This role is left to the United Nations as the ICAO cannot deal with issues of political nature.

If the ICAO had the power to close airspaces when there was impending threats to civil aviation of $\mathrm{MH} \mathrm{17,} \mathrm{the} \mathrm{disaster} \mathrm{could}$ have been averted. Ukraine did not close the airspace as it would lose out on fees paid by air carriers. Hence, it is the submission of the author that it is the ICAO which must be given this responsibility and power to enforce upon the States to provide compensation in cases of any accidents over their air space as a result of any lapses on their part.

The issues raised by the author are the need of the hour as many passengers could be left waiting for decades for justice and compensation. The minimum expectation of the families of those who died in the accident is the award of a substantial amount of compensation. It is unfair to make them knock at the doors of justice to claim compensation; especially when the resolution of disputes could take decades.

Further, the absence of international regulations to ensure the liability of sovereign states for damages would affect the passenger confidence in air travel and reforms suggested by the author are necessary for the growing future of the aviation industry. 